\title{
Rancang Bangun Autonomous Robot Tank dengan Metode Waypoint Berbasis Raspberry Pi
}

\section{The Design of Autonomous Robot Tank with Waypoint Method Based on Raspberry $\mathrm{Pi}$}

\author{
Juanda Rahimatullah ${ }^{1 *}$, Nur Rachman Supadmana Muda $^{2}$, MHD Iqbal Fahmi ${ }^{3}$, Zani Akbari ${ }^{4}$ \\ Jurusan Telekomunikasi Politeknik Angkatan Darat \\ Jalan Raya Pendem Batu-Malang 65324-Telp (0341) 461504 \\ komd4212@gmail.com ${ }^{1 *}$
}

\begin{abstract}
Abstrak - Pada era perang modern, robot digunakan untuk melakukan penyerangan terhadap sasaran untuk memperkecil kerugian personel. Autonomous robot tank merupakan robot yang bergerak otomatis dengan menghindari rintangan yang berada didepannya. Sistem Navigasi Waypoint digunakan pada autonomous robot tank untuk menentukan pergerakan robot dari titik kordinat satu ke titik kordinat lain berdasarkan sistem kordinat bumi, menentukan arah, dan jarak dalam mencari sasaran tanpa harus full control. Operator hanya menentukan titik sasaran yang akan dilakukan penyerangan maka robot tank akan dengan sendirinya bergerak menuju sasaran. Modul GPS akan membaca koordinat dimana posisi dari mobile robot berada, dan modul magnetic compass digunakan untuk menentukan arah tujuan robot tank bergerak. Obstacle avoidance system menerima sinyal dari sensor ultrasonic ketika ada benda halangan didepannya untuk menghindari benda tersebut. Hasil pengujian didapatkan bahwa sistem navigasi waypoint pada robot dapat menuju tepat ke daerah sasaran musuh serta menghindari halangan di depannya dan selanjutnya kembali pada jalur navigasi menuju titik yang sudah ditentukan. Penelitian ini sangat berguna bagi TNI dalam melaksanakan penyerangan maupun pengintaian pada daerah operasi dengan memanfaatkan autonomous robot tank.
\end{abstract}

Kata Kunci: Autonomous robot tank, waypoint, obstacle avoidance system.

\begin{abstract}
In the era of modern warfare, robots are used to carry out attacks on targets to reduce personnel losses. An autonomous robot tank is a robot that moves automatically by avoiding obstacles in front of him. The Waypoint Navigation System is a method to determine the direction, distance, and movement of robot from start coordinate point to target coordinate point based on the earth's coordinate system automatically. The user only determines the target point to be attacked, then the robot tank will automatically move towards the target. The GPS module will read the position coordinates of the cellular robot, and the magnetic compass module was used to determine the direction the robot tank. The obstacle avoidance system receives a signal from the compilation ultrasonic sensor when there is a barrier in front of it to avoid that object. The simulation results show that the waypoint navigation system on the robot can go directly to the enemy target area and avoid obstacles in front of him and then back on the navigation path to the specified point. This research is very useful for the TNI in carrying out attacks or reconnaissance in the field of operations by utilizing autonomous robot tanks.
\end{abstract}

Keywords: Autonomous robot tank, waypoint, obstacle avoidance system.

TELKA, Vol.6, No.1, Mei 2020, pp. 29 39

ISSN (e): 2540-9123

ISSN (p): 2502-1982 


\section{Pendahuluan}

Peperangan di masa depan tidak lagi memakan sumber daya manusia di lini depan melainkan akan digantikan dengan wahana yang dilengkapi peralatan canggih yang dapat bergerak secara mandiri tanpa harus dikendalikan secara penuh oleh manusia. Perkembangan ilmu pengetahuan dan teknologi robotika telah sampai pada zaman autonomous robot[1]. Teknologi mobile robot menjadi peran utama dalam aplikasi di dunia militer, dalam pengaplikasiannya mobile robot dituntut agar dapat bergerak secara mandiri tanpa ada lagi operator dalam pengoperasiannya agar mengurangi jatuhnya korban personil. Pada penelitian sebelumnya sistem navigasi pada mobile robot di implementasikan dengan compass dengan melihat arah gerak mobile robot dapat mengikuti rute perjalanan dengan tingkat akurasi pada modul compass[2]. Penelitian yang lainnya dengan menggunakan kamera sebagai sensor vision untuk mendeteksi street mark dan sensor jarak ultrasonik untuk mendeteksi adanya halangan sebagai pengaman agar tidak terjadi tabrakan terhadap mobil[3]. Pada navigasi waypoint adalah suatu metode untuk mengatur gerak dari suatu posisi ke posisi lain yang dituju, dengan mengasumsikan setiap posisi dalam proses pergerakannya menjadi suatu titik dalam sistem koordinat tertentu (latitude dan longitude bila berdasarkan sistem koordinat Bumi)[1].

Dihadapkan pada perkembangan teknologi dibidang persenjataan, pengembangan teknologi alutsista saat ini terus bergerak ke arah otomasi robotika dengan kendali jarak jauh, dalam hal ini penggunaan otomasi robotika tersebut dapat mendukung TNI AD dalam melaksanakan tugas operasi penyerangan dan pengintaian. Autonomous Robot ini bisa diterapkan pada robot tank yang dinamakan dengan autonomous robot tank. Robot tank dapat bergerak secara otomatis menghindari rintangan yang berada di depannya, dan dapat berpindah posisi secara mandiri. Sistem navigasi waypoint dirancang agar autonomous robot tank dapat mengetahui arah gerak dan posisi sesuai dengan sistem koordinat Bumi, dapat mengoreksi arah gerak (bearing correction) dan odometer sehingga dapat meningkatkan akurasi untuk mencapai posisi yang dituju pada rute yang sudah ditentukan oleh operator. Sistem navigasi menjadi bagian terpenting pada autonomous robot tank agar dapat bekerja secara ganda saat bergerak menggunakan waypoint, pergerakan robot harus mempunyai nilai akurasi yang mendekati nilai eror terendah agar robot tank dapat menuju daerah musuh dengan tepat sasaran yang dilengkapi dengan sistem pendukung lainnya yakni obstacle avoidance system, sehingga robot dapat bergerak menghindari halangan yang ada di depannya dengan memasukan titik navigasi daerah musuh dan memberikan perintah dari jarak jauh untuk melakukan pengintaian ataupun penyerangan di daerah operasi agar musuh dapat dilumpuhkan dengan cepat dan tepat untuk membantu tugas pokok TNI AD dalam menjaga kedaulatan NKRI sehingga dapat mengurangi kerugian personil.

\section{Metode Penelitian}

Penyusunan dalam penelitian ini bermaksud menjawab rumusan masalah yang ada seperti pada pendahuluan sehingga mempunyai tujuan agar masalah tersebut dapat terealisasi. Penulis mengunakan metode studi literatur dan eksperimen. Berdasarkan pada hasil pengujian akan diketahui besarnya eror yang didapatkan dari titik waypoint dan titik lintasan robot tank.

\subsection{Spesifikasi alat}

Langkah sebelum perancangan design alat maka harus dilakukan penentuan alat yang akan digunakan, alat yang digunakan tersebut juga harus menggunakan kualitas yang cukup baik agar bisa didapatkan efektifitas kineja alat yang maksimal, meliputi sebagai berikut:

a. Penggerak roda rantai digunakan agar robot dapat melewati berbagai medan lintasan karena mempunyai kontur yang sangat kokoh.

b. Aplikasi waypoint untuk memasukan perintah dengan menentukan titik sasaran yang tidak terbatas, artinya penentuan titik waypoint bisa diberikan lebih dari satu ataupun dua titik.

c. Penggunaan modul GPS Ublox NEO-6M sebagai penentu koordinat robot memiliki tingkat akurasi 2,5 meter berdasarkan WGS`84. Sensitifitas mulai $-147 \mathrm{dBm}$ pada cold start, $-156 \mathrm{dBm}$ pada hot start[4]. 
d. Ultrasonic HC-SR04 pada obstacle avoidance system sebagai pendeteksi benda atau halangan didepan robot tank, HC-SR04 akan mengeluarkan sinyal ultrasonic sebesar 8 cycle dan selanjutnya HC-SR04 akan memberikan pulsa $100 \mu \mathrm{s}-18 \mathrm{~ms}$ pada outputnya tergantung pada informasi jarak pantulan objek yang diterima[5].

e. Motor MY1016 dengan daya 24V 250Watt sebagai motor penggerak robot tank, dilengkapi dengan roda rantai tambahan yang dapat digunakan secara fleksibel saat dibutuhkan untuk menanjak pada tangga ataupun secara otomatis melipat pada saat jalan yang rata.

f. Raspberry Pi 4 digunakan sebagai sistem kendali navigasi waypoint robot, selain sebagai pengolah data kendali robot Raspberry Pi dihubungkan dengan internet dan web server dapat dikendalikan secara remote dari jarak jauh[6].

g. Arduino nano berfungsi bekeja mengolah data yang dikirim dari sensor kemudian Arduino mengirimkan sinyal ke raspberry pi sehingga putaran roda dapat diatur dan robot tank bergerak menghindari halangan didepannya. Arduino Nano diciptakan dengan basis mikrokontroler ATmega328 (untuk Arduino Nano versi 3.x)[7].

h. Baterai lipo 2 cell dengan kapasitas 2200mAh digunakan untuk memisahkan tegangan mini komputer raspberry pi agar terhindar dari komponen induktor yang besar seperti motor[3].

\subsection{Blok Diagram Alat}

\subsubsection{Blok Diagram Robot Tank}

Perancangan dilakukan secara bertahap, dimulai dari blok diagram keseluruhan, kemudian dibuat blok diagram tiap tahapan. Blok diagram secara keseluruhan ditampilkan pada Gambar 1. Gambar 1 merupakan blok diagram robot tank secara keseluruhan, dibagi menjadi 3 bagian besar, antara lain:

a. Waypoint system memberikan data inputan kepada raspberry pi tentang koordinat waypoint, jarak antara benda di depannya, dan arah gerak robot tank. Pada waypoint system terdapat 3 sensor yang digunakan yakni GPS U-Blox Neo 6M, Ultrasonic HCSR04, dan Compass Modul GY-271 HMC5883L.

b. Application merupakan sistem yang menggunakan metode interaksi antar muka atau GUI (Graphical User Interface) untuk menerjemahkan bahasa pemrograman PHP (Hypertext Preprocessor) dengan operator, sehingga aplikasi control dapat memonitoring dan mengendalikan arah gerak robot melalui web server dengan komunikasi data lewat internet.

c. Propulsion system akan menghasilkan tenaga penggerak dengan menggunakan sistem penggerak differential drive, perbedaan putaran motor penggerak tersebut diatur oleh microprocessor ke speed control MY1016, sinyal pulsa yang dikirim oleh raspberry pi mengatur besar kecilnya arus yang dikirim ke motor DC MY1016 250W. 


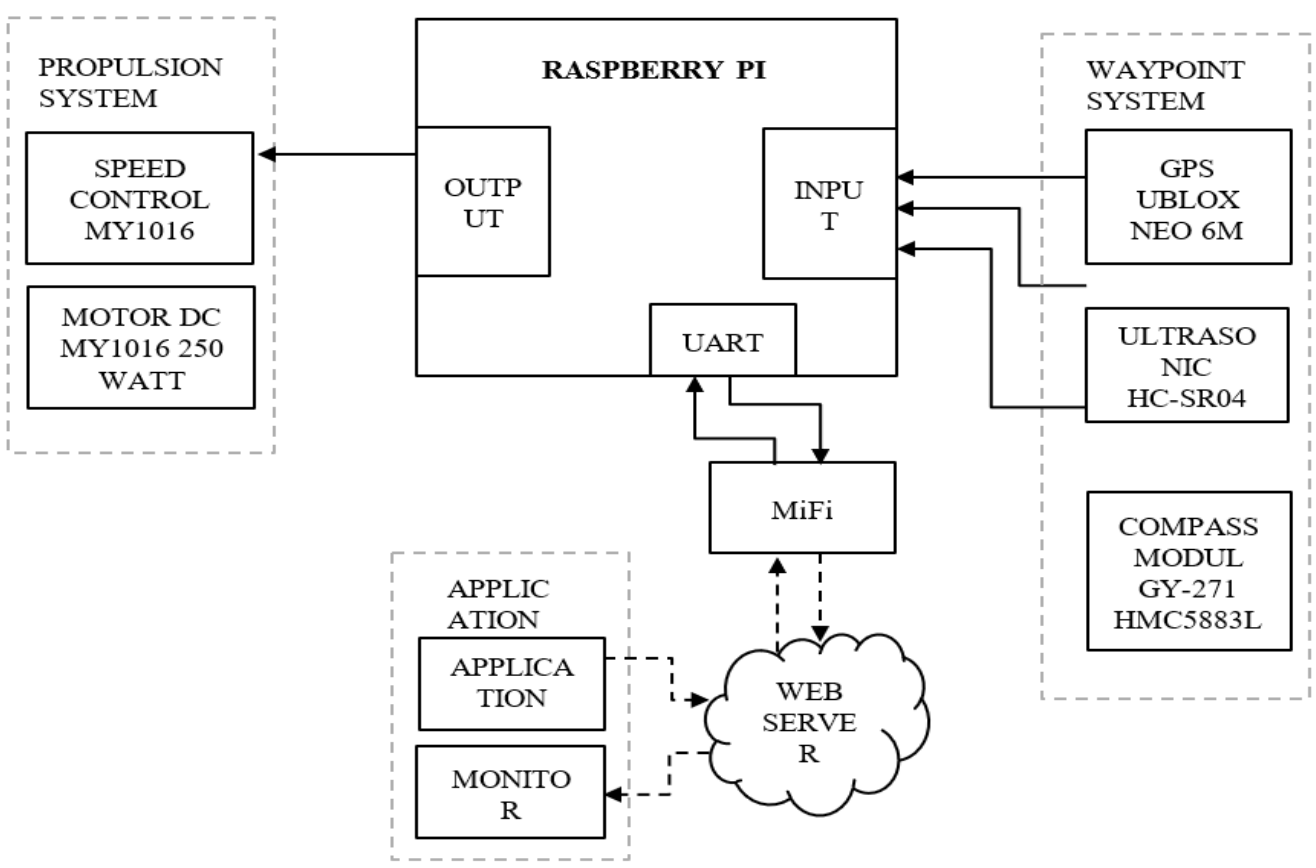

Gambar 1. Diagram blok sistem keseluruhan.

\subsubsection{Diagram Alir System Waypoint}

Perancangan pada system waypoint bertujuan untuk mendapatkan implementasi perhitungan algorithma yang mengendalikan navigasi robot tank pada mode waypoint. Diagram alir proses dan output kerangka konsep penelitian ditunjukan pada Gambar 2.

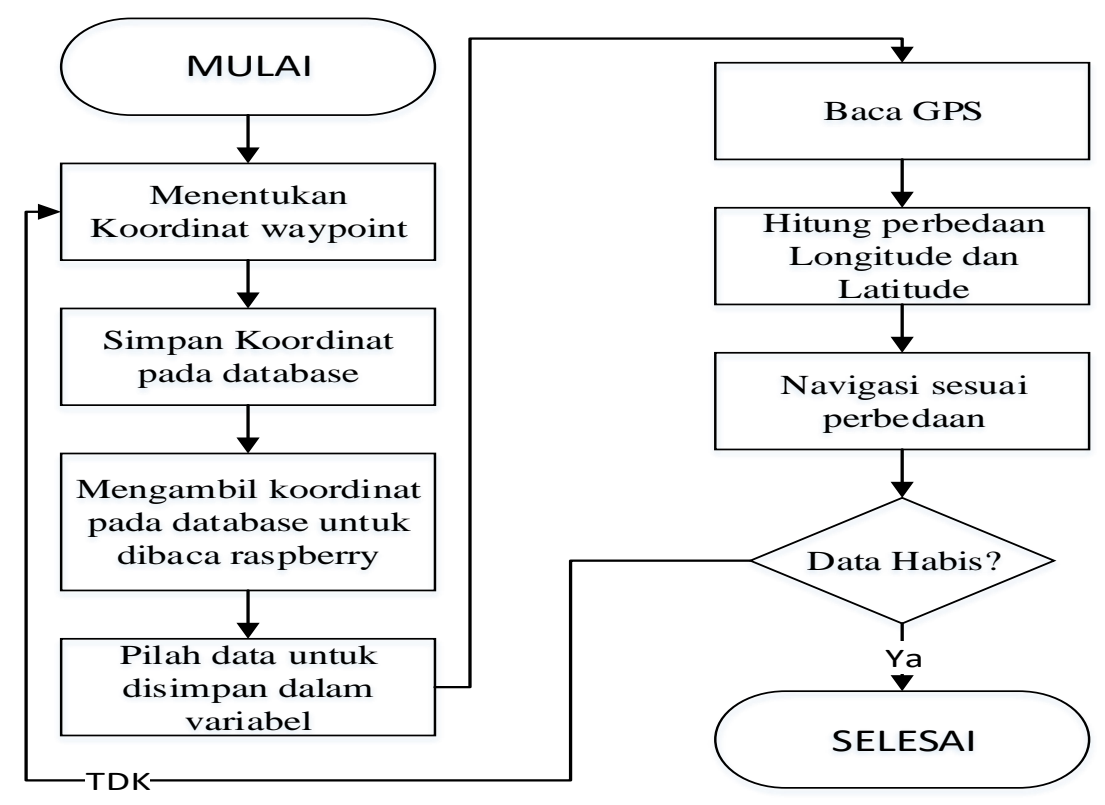

Gambar 2. Diagram alir waypoint system.

Gambar 2 merupakan diagram alir waypoint system. Setelah titik koordinat ditentukan, datadata keluaran GPS dan magnetic compass tersebut dikirimkan ke raspberry pi melalui komunikasi serial. Data yang didapatkan dari raspberry pi diproses untuk memperoleh koordinat, kemudian Mifi mengirimkan data tersebut ke server. 
Untuk menghitung nilai perbedaan $\mathrm{dx}$ dan dy dapat dilakukan dengan menggunakan persamaan:

$$
\begin{aligned}
& \text { dlat }(\text { Differential Latitude })=\text { latitude_target }- \text { latitude_gps } \\
& \text { dlong(Differential Longitude })=\text { longitude_target }- \text { longitude_gps }
\end{aligned}
$$

hasil dari rumus ini menentukan bagaimana robot harus bernavigasi, untuk menghitung nilai eror pada waypoint system [8]

$$
\Sigma \% \text { error }=\frac{\text { Nilai Waypoint }- \text { Nilai Lintasan }}{\text { Nilai } \text { Waypoint }} \times 100 \%
$$

\subsubsection{Diagram Alir Obstacle Avoidance System}

Autonomous robot tank selain dirancang bergerak berdasarkan navigasi waypoint juga dapat bergerak menghindari halangan obstacle avoidance system. Dengan pengaplikasian sensor HCSR04 yang ditambahkan untuk mengenali objek didepan robot tank, saat sensor mendeteksi objek, mikrokontroller akan memerintahkan robot bergerak ke kanan atau ke kiri Algoritma tersebut di jelaskan pada Gambar 3.

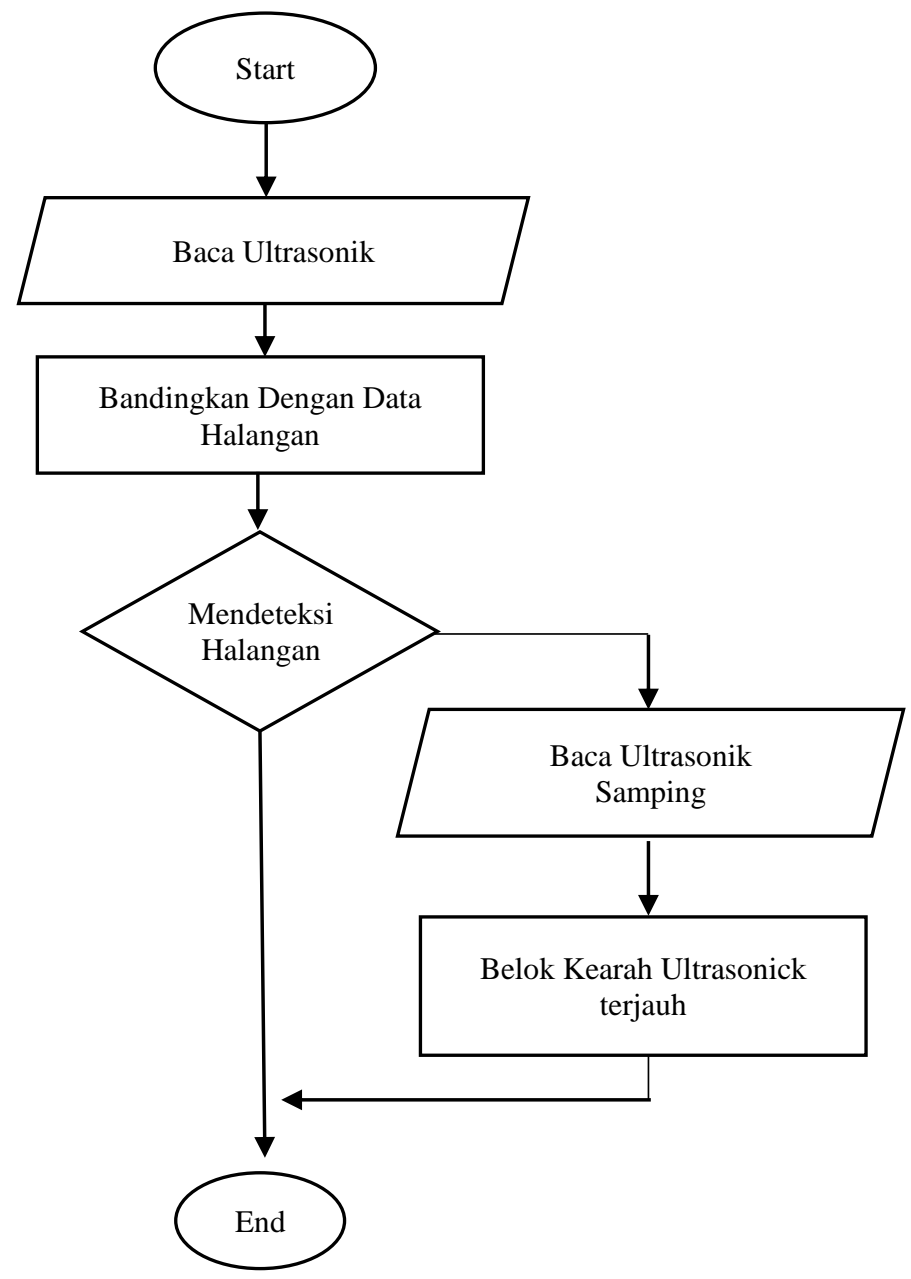

Gambar 3. Diagram alir obstacle avoidance system.

Gambar 3 menunjukkan bahwa sensor melakukan pembacaan secara continuous selama robot berjalan, ketika mendeteksi halangan maka akan berbelok kekanan kekiri atau menjauhi benda didepannya, setelah melakukan pengindaran robot akan kembali bernavigasi sesuai lintasan waypoint. 


\subsection{Perancangan Alat}

\subsubsection{Perancangan Perangkat Lunak}

Pembuatan aplikasi software dirancang dengan tampilan yang dapat mudah dipahami dan menarik dengan menggunakan bahasa PHP, PHP adalah sebuah bahasa script server side yang dapat digunakan dengan bahasa HTML atau dokumen secara bersamaan untuk membangun sebuah aplikasi web[9]. Basis data secara real-time digunakan berhubungan dengan kinerja robot dan skalabilitasnya, basis data akan melakukan fugsi-fungsi penggunaan seperti otentikasi operator, penanganan sesi dan penyimpan data (database). Selain itu didalam aplikasi dapat menjelaskan kondisi robot dimana dalam aplikasi terdapat koordinat robot, citra hasil pengintaian, dan penggunaan baterai selama robot bergerak serta didalam aplikasi waypoint tersebut juga dilengkapi remote kontrol robot yang dapat digunakan di semua perangkat Operating Sistem, yaitu dengan menggunakan Aplikasi yang berbasis Web Server yang ditunjukan pada Gambar 4.

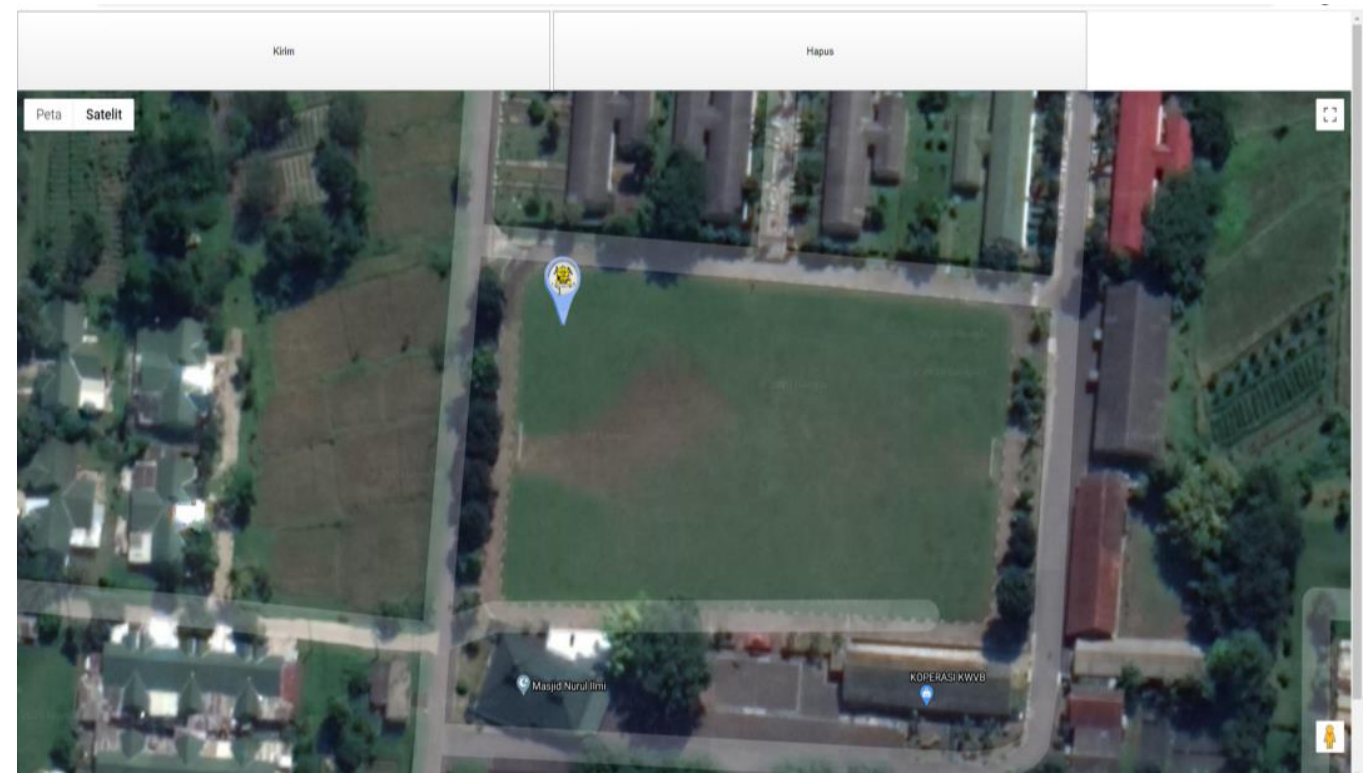

Gambar 4. Aplikasi antarmuka waypoint pada webpage.

Gambar 4 merupakan tampilan dari aplikasi software dimana tampilan peta mengambil dari google maps dan titik waypoint dapat ditentukan jumlahnya tanpa batas, tombol kirim diatas merupakan buttton untuk mengirimkan data waypoint dari aplikasi ke robot melalui internet.

\subsubsection{Perancangan Robot Tank}

Perancangan bentuk robot berfokus pada kemampuan robot dalam menaiki tangga, sehingga diperlukan tambahan lengan robot pada bagian depan robot yang dapat menyatu dengan body dan efektif saat digunakan. Penataan komponen penting dilakukan karena akan mempengaruhi kinerja dari komponen tersebut, terutama pada GPS Ublox NEO-6M dan modul kompas harus diletakkan di ruang terbuka yang tidak ada halangan di bagian atas supaya bisa terhubung langsung dengan satelit seperti pada Gambar 5. 


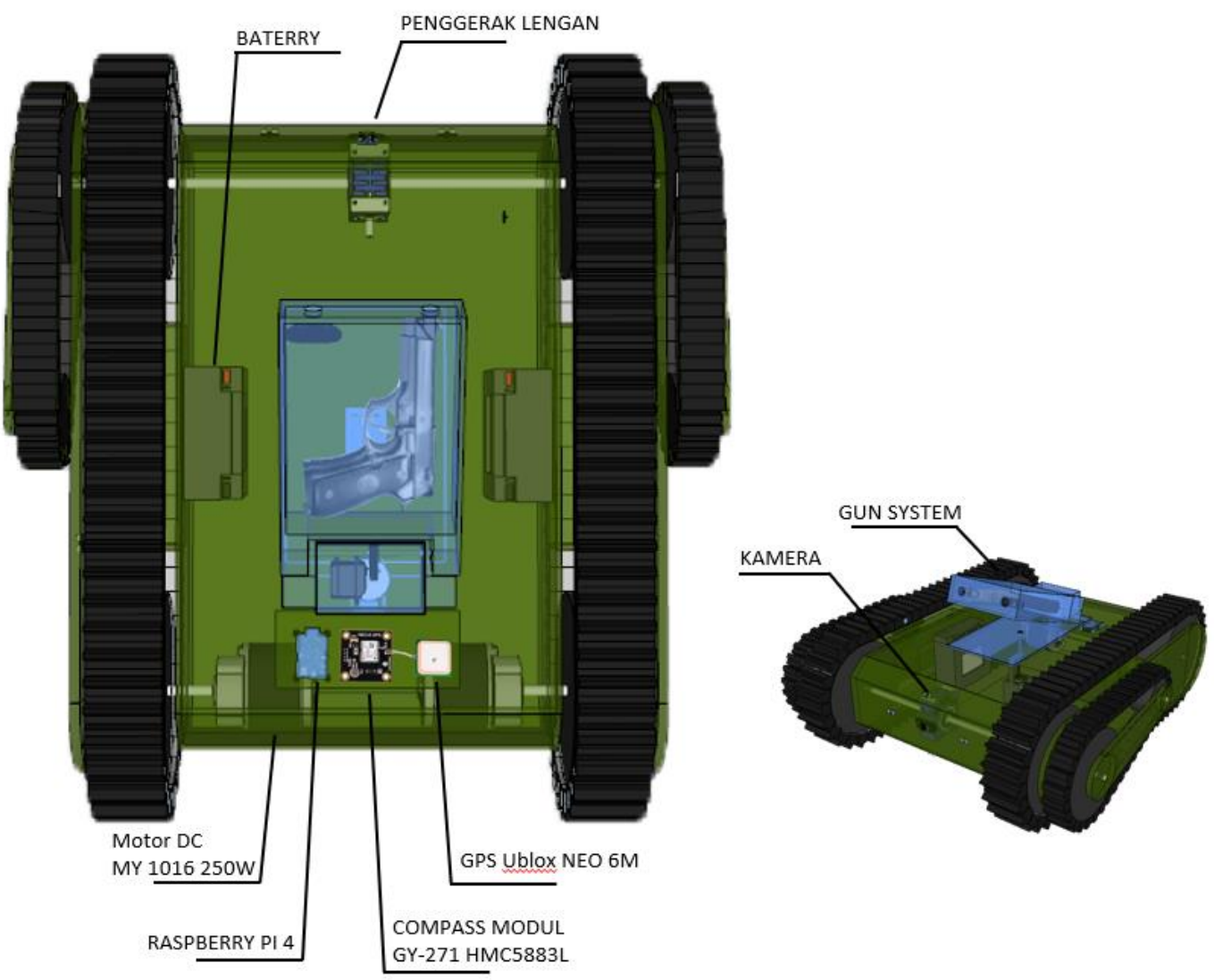

Gambar 5. Perancangan robot tank.

Gambar 5 merupakan desain perancangan robot dengan dilengkapi keterangan peletakan komponen robot, terdapat dua buah gambar dengan tampak atas dan tampak samping depan robot.

\section{Hasil dan Pembahasan}

Pengujian dan analisis dilaksanakan menjadi dua bagian yaitu pengujian navigasi robot tank dengan rintangan dan pengujian navigasi robot tank tanpa rintangan. Pengujian dilakukan dengan memberikan koordinat sasaran pada robot tank, selanjutnya apakah robot tank dapat bergerak menuju sasaran yang telah ditentukan. Pengujian dilaksanakan di lapangan Poltekad sebagai tujuan sasaran.

\subsection{Pengujian Navigasi Robot Tank Dengan Rintangan}

Pengujian navigasi dengan rintangan maka robot tank memiliki dua sistem yang bekerja, selain robot tank dapat menuju sasaran melalui titik waypoint yang tentukan maka robot tank juga harus melewati rintangan seperti yang ditunjukan pada Gambar 6. 


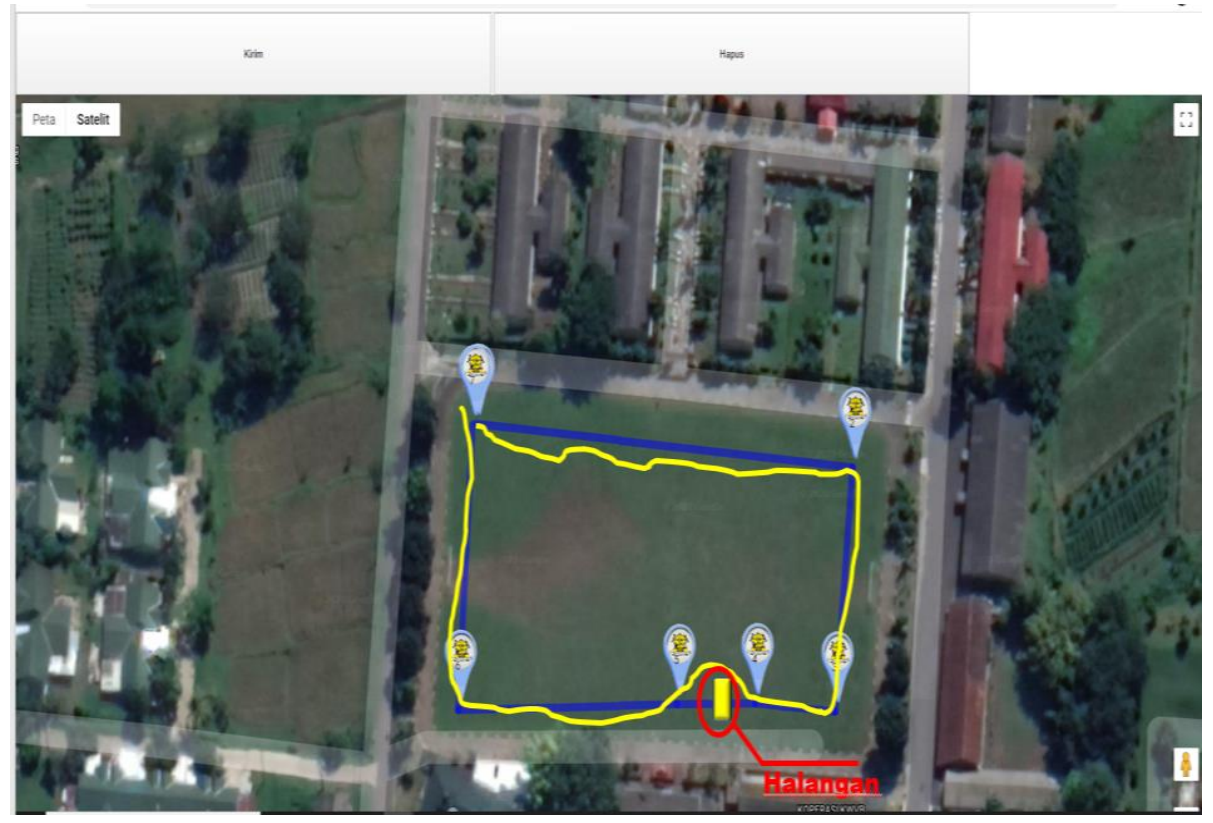

Gambar 6. Rute waypoint dan lintasan robot tank dengan rintangan.

Gambar 6 menunjukkan terdapat lintasan robot dalam bergerak dengan diletakkan sebuah rintangan berwarna kuning antara titik ke 4 dan ke 5 agar dapat diketahui obstacle avoidance system dapat berfungsi dengan baik. Niilai data berupa selisih error koordinat antara titik waypoint dengan lintasan yang dilewati oleh robot dengan toleransi 1 meter, seperti pada Tabel 1.

Tabel 1. Data latitude dan longitude dengan rintangan.

\begin{tabular}{lcccccc}
\hline \multicolumn{1}{c}{ Lokasi Tujuan } & $\begin{array}{c}\text { Lat } \\
\text { Waypoint }\end{array}$ & $\begin{array}{c}\text { Long } \\
\text { Waypoint }\end{array}$ & $\begin{array}{c}\text { Lat } \\
\text { Lintasan }\end{array}$ & $\begin{array}{c}\text { Long } \\
\text { Lintasan }\end{array}$ & $\begin{array}{c}\text { Beda } \\
\text { Sudut } \\
\left({ }^{(}\right)\end{array}$ & $\begin{array}{c}\text { Eror } \\
(\%)\end{array}$ \\
\hline Start (Home) & -7.89494563 & 112.58374125 & -7.89496035 & 112.58376435 & 8.42 & 2.07 \\
Waypoint 1 & -7.89502002 & 112.58465321 & -7.89503012 & 112.58466121 & -5.16 & 1.35 \\
Waypoint 2 & -7.89543979 & 112.58461028 & -7.89543227 & 112.58462215 & -1.16 & 0.84 \\
Awal Halangan & -7.89544512 & 112.58435279 & -7.89644411 & 112.58435420 & -9.04 & 2.41 \\
Akhir Halangan & -7.89546636 & 112.58421868 & -7.89548788 & 112.58421945 & 10.24 & 2.73 \\
Waypoint 3 & -7.89536541 & 112.58375734 & -7.89536251 & 112.58375862 & -1.03 & 0.35 \\
Waypoint 4 (Home) & -7.89494563 & 112.58374125 & -7.89495974 & 112.58376752 & 8.38 & 2.02 \\
\hline
\end{tabular}

Dari Tabel 1 didapatkan beda sudut antara lintasan dengan waypoint yang telah ditentukan dihitung dengan menggunakan persamaan (1) dan (2). Nilai error pada waypoint system juga dapat dihitung dengan menggunakan rumus tersebut. 


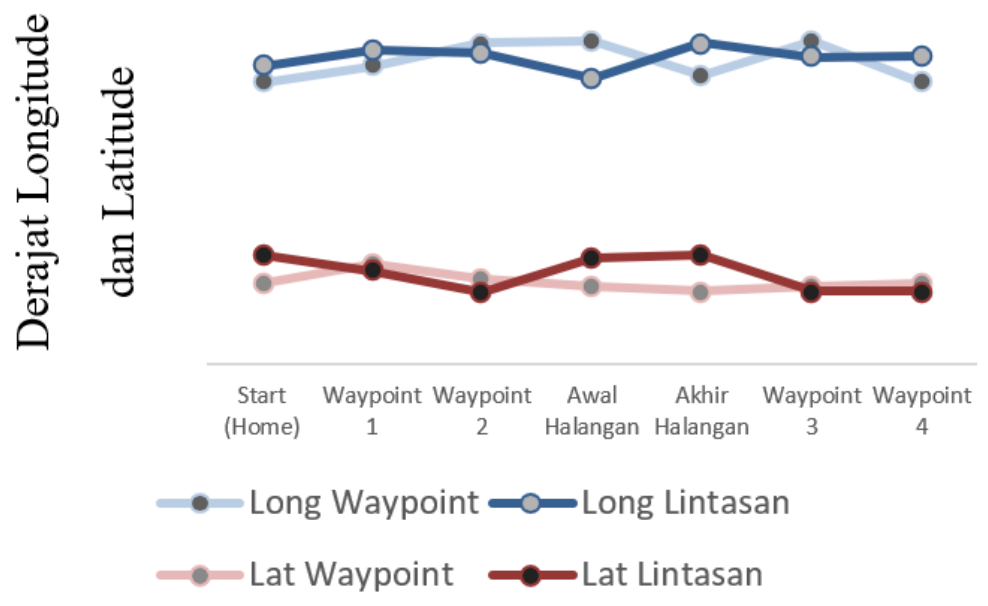

Gambar 7. Derajat latitude dan longitude dengan rintangan.

Gambar 7 merupakan grafik dari 4 titik dan satu halangan yang diujikan terdapat beda sudut lintasan dengan waypoint dan data obstacle avoidance system juga didapatkan saat robot tank bertemu halangan didepannya. Dari data ini menunjukkan bahwa robot mencari lintasan lain dengan berbelok ke-kanan atau ke-kiri kemudian setelah halangan terlewati robot akan melanjutkan ke lintasan waypoint semula.

\subsection{Pengujian Navigasi Robot Tank Tanpa Rintangan}

Data uji yang diambil pada pengujian navigasi robot tank tanpa ada rintangan ditunjukkan pada Tabel 2. Pengujian dilakukan untuk mengetahui besar error yang diperoleh robot tank dalam melakukan pergerakan menuju sasaran seperti pada Gambar 8. Toleransi error tersebut didapatkan dari perhitungan longitude dan latitude pada robot tank.

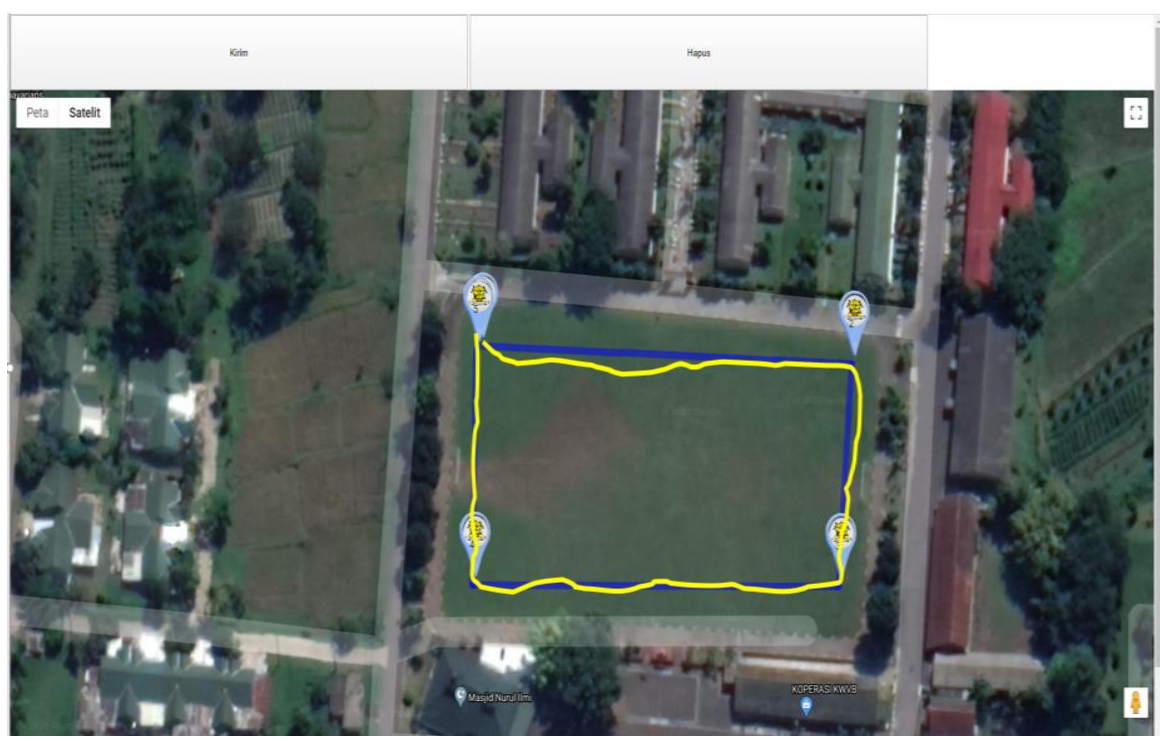

Gambar 8. Rute waypoint dan lintasan robot tank tanpa rintangan. 
Tabel 2. Data latitude dan longitude tanpa rintangan

\begin{tabular}{lcccccc}
\hline \multicolumn{1}{c}{ Lokasi Tujuan } & $\begin{array}{c}\text { Lat } \\
\text { Waypoint }\end{array}$ & $\begin{array}{c}\text { Long } \\
\text { Waypoint }\end{array}$ & $\begin{array}{c}\text { Lat } \\
\text { Lintasan }\end{array}$ & $\begin{array}{c}\text { Long } \\
\text { Lintasan }\end{array}$ & $\begin{array}{c}\text { Beda } \\
\text { Sudut } \\
\left({ }^{0}\right)\end{array}$ & $\begin{array}{c}\text { Eror } \\
(\%)\end{array}$ \\
\hline Start (Home) & -7.89492437 & 112.58378953 & -7.89494704 & 112.58372875 & -9.61 & 2.33 \\
Waypoint 1 & -7.89544512 & 112.58461565 & -7.89546016 & 112.58462112 & -5.14 & 1.95 \\
Waypoint 2 & -7.89493512 & 112.58430451 & -7.89492561 & 112.58430913 & 2.27 & 1.16 \\
Waypoint 3 & -7.89531758 & 112.58373588 & -7.89531779 & 112.58373622 & -0.12 & 0.029 \\
Waypoint 4 (Home) & -7.89492537 & 112.58377853 & -7.89492888 & 112.58371553 & 0.58 & 0.14 \\
\hline
\end{tabular}

Gambar 8. merupakan tampilan lintasan navigasi robot tanpa rintangan, dimana warna biru merupakan lintasan waypoint dan warna kuning adalah lintasan robot. Diberikan 4 titik tujuan agar dapat diketahui navigasi robot berfungsi dengan baik. Nilai data berupa selisih error koordinat antara titik waypoint dengan lintasan yang dilewati oleh robot dengan toleransi 1 meter, ditunjukkan pada Tabel 2.

Pada Tabel 2. didapatkan beda sudut antara lintasan dengan waypoint yang telah ditentukan disitu dihitung dengan menggunakan rumus perbedaan dlat dan dlong seperti yang ada di atas. Nilai error pada waypoint system juga dapat dihitung dengan menggunakan rumus tersebut.

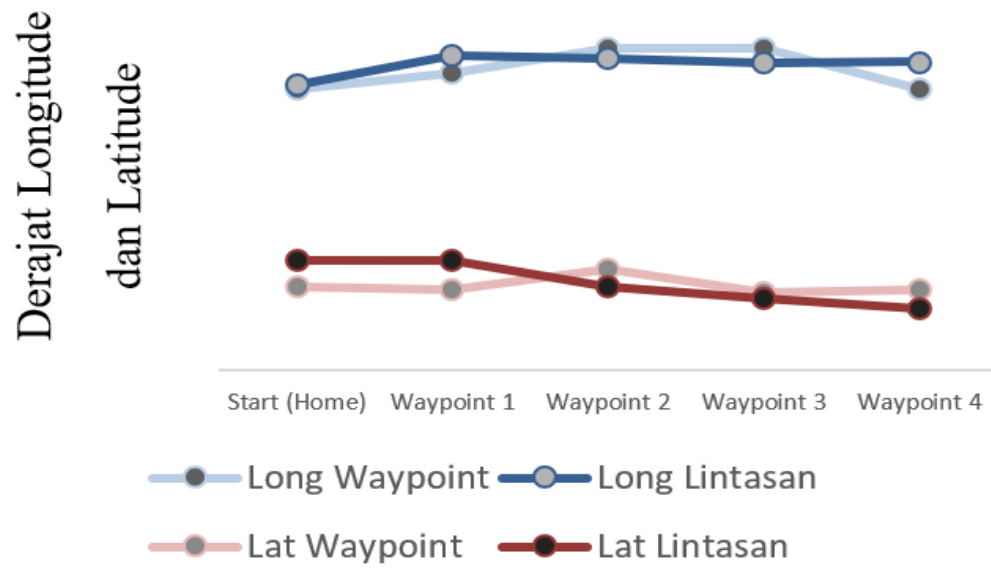

Gambar 9. Derajat latitude dan longitude tanpa rintangan.

Gambar 9 merupakan grafik dari 4 titik yang telah ditentukan pada aplikasi waypoint didapatkan nilai error paling besar dengan sudut $10.14^{\circ}$ dan sudut yang terkecil yakni sebesar $0.12^{0}$, dimana beda sudut dan nilai error tersebut akan dihitung dengan menggunakan rumus Haversine Formula[10]:

$$
\begin{aligned}
& a=\sin ^{2}\left(\frac{\Delta \varphi}{2}\right)+\cos \varphi_{1} \cdot \cos \varphi_{2} \cdot \sin ^{2}\left(\frac{\Delta \lambda}{2}\right), \\
& c=2 \cdot \operatorname{atan} 2(\sqrt{a}, \sqrt{(1-a)}), \\
& d=R \cdot c,
\end{aligned}
$$

dengan $\varphi$ adalah latitude, $\lambda$ adalah longitude, $R$ adalah jari-jari bumi $(\approx 6.371 \mathrm{~km}), d$ adalah jarak haversine, $c$ adalah jarak sudut dalam radian, dan $a$ adalah kuadrat dari setengah panjang koordinat antara dua poin. 


\section{Kesimpulan}

Setelah dilaksanakan pengujian dan analisis sistem navigasi waypoint dengan obstacle avoidance system pada autonomous robot tank, didapatkan beberapa kesimpulan sebagai berikut: 1) nilai eror akurasi terendah sebesar $0,029 \%$ dan tertinggi $2,33 \%$ sehingga robot tank dapat menuju sasaran dengan tepat, 2) Aplikasi waypoint dapat mengirimkan perintah kendali otomatis dan menampilkan pergerakan robot secara realtime pada saat robot melewati lintasan waypoint, dan 3) Obstacle Avoidance System berfungsi dengan baik dalam menghindari benda yang akan ditabrak.

\section{Referensi}

[1] A. S. Taufik, "Sistem Navigasi Waypoint pada Autonomous Mobile Robot," J. Mhs. TEUB, vol. 1, no. 1, pp. 1-6, 2013.

[2] D. Liani and A. Silvia, "Sistem Navigasi Pada Mobile Robot Dalam Penentuan Arah dan Pemetaan Posisi," Seminar Nasional Teknologi Informasi, Bisnis, dan Desain, pp. 129134, 2017.

[3] M. Taufiqurrahman, Sumardi, and M. A. Riyadi, "Perancangan Self Driving Dengan Metode Kontrol Pd Pada Sistem Tracking Autonomous Car," Transient, vol. 5, no. 2, p. 174, 2016.

[4] A. P. Kurniawan, G. A. Mutiara, and G. I. Hapsari, "Pengiriman Informasi GPS ( Global Positioning System ) Berupa Teks Melalui Wireless pada AR Drone 2 . 0," Univ. Telkom, vol. 1, no. 2, pp. 0-7, 2000.

[5] R. Dikairono, T. A. Sardjono, and L. Yulianto, "Sistem Navigasi Dan Penghindar Rintangan Pada Mobile Robot Menggunakan Gps Dan Pengukur Jarak Ultrasonik," JAVA J. Electr. Electron. Eng., vol. 11, no. 1, pp. 1-6, 2016.

[6] J. T. Erma Susanti, "Pengembangan Sistem Pemantau dan Pengendalian Menggunakan Raspberry Pi dan Firebase," Konf. Nas. Teknol. Inf. dan Komun., no. November, pp. 144153, 2016.

[7] M. T. fredy, Dr.Ir. Sony Sumaryo,m.t, Ir.Porman Pangaribuan, "Perancangan Sistem Monitoring Sepeda Motor Mengunakan Modul Gps Berbasis Android," e-proceeding Eng., vol. 5, no. 3, p. 4179, 2018.

[8] I. Amalian Tafa, D. Suryadi, T. Pontia, "Analisis Tingkat Akurasi Global Positioning System Smartphone Dalam Menentukan Titik Lokasi Pada Google Map," Jurnal Elektro, Universitas Tanjungpura, 2018.

[9] M. I. Ashshidiq, M. A. Setiawan, and F. Wahid, "Aplikasi Berbasis Web Pemetaan Informasi pada Gambar Bitmap,” Media Inform., vol. 4, no. 1, pp. 13-26, 2006, doi: 10.20885/informatika.vol4.iss1.art2.

[10] Suraya and M. Sholeh, "Implementation of Geography Information Systems in Searching System for The Closest Locations of Museum," Int. J. Sci. Res. Publ., vol. 8, no. 6, pp. 405-409, 2018, doi: 10.29322/ijsrp.8.6.2018.p7853. 